\title{
Endoscopic band ligation for weight loss
}

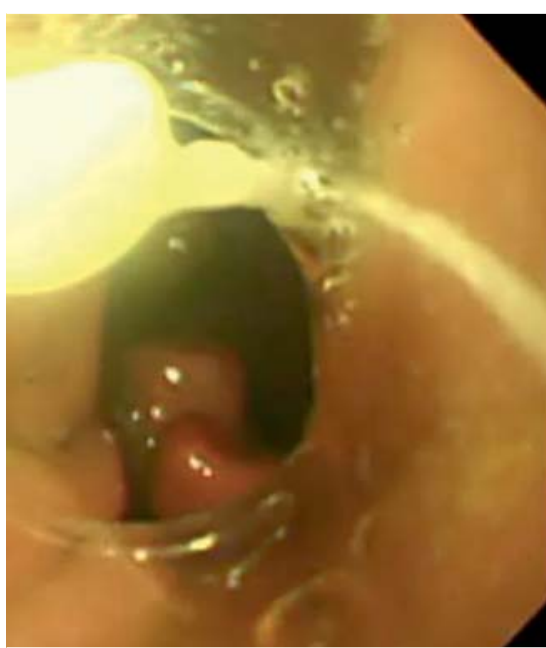

- Fig. 1 Endoscopic view showing the band ligation cap.

To the best of our knowledge, this is the first study to use endoscopic band ligation for weight loss in a 30-year-old woman, who had an initial weight of $85 \mathrm{~kg}$ (height $155 \mathrm{~cm}$; body mass index [BMI] $35.4 \mathrm{~kg} / \mathrm{m}^{2}$ ). Endoscopy was performed with the patient sedated using propofol. All ligatures were applied in the gastric body, starting at the distal body; five parallel rows were created, with the last one in the proximal body, using 33 bands ( $\triangleright$ Fig. 1). The entire procedure was completed in 30 minutes. Oxygen was used for endoscopic air insufflation. Notably, no immediate complications occurred during endoscopy ( $\bullet$ Video 1 ).

The patient did well after the procedure and was discharged after 2 hours. In the first 3 days, she complained of mild nausea, vomiting, and epigastric pain, which were controlled by medications (pantoprazole $40 \mathrm{mg}$ twice daily for the first month, plus antiemetics and antispasmodics on demand). For 2 weeks, she was given a fully liquid diet, followed by an 800 -calorie soft diet for another 2 weeks. The patient reported early satiety following the procedure. Follow-up endoscopy after 1 month revealed nice linear scars of healed ulcers in the gastric body

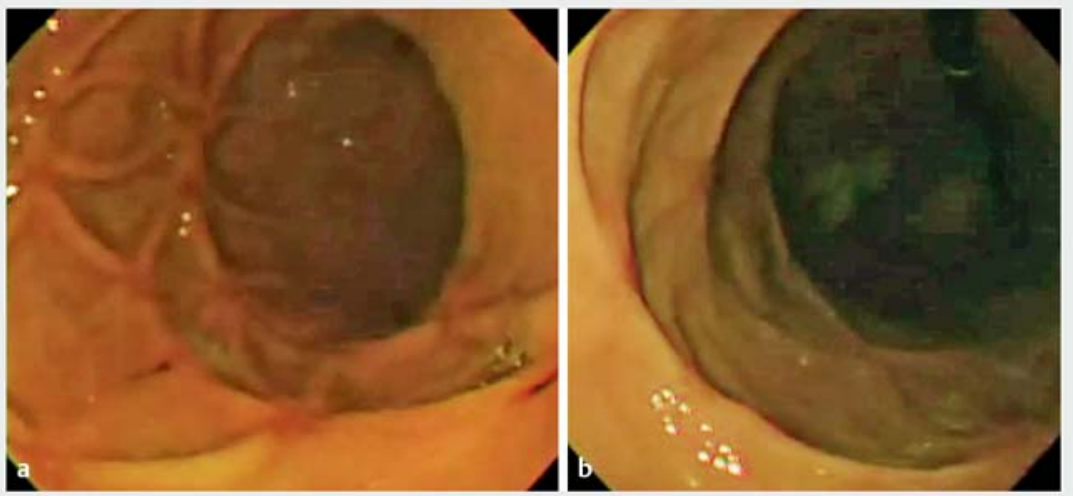

- Fig. 2 Endoscopic views 1 month after the procedure showing nice linear scars of healed post-band ulcers in the body a on forward view; $\mathbf{b}$ on retroversion.

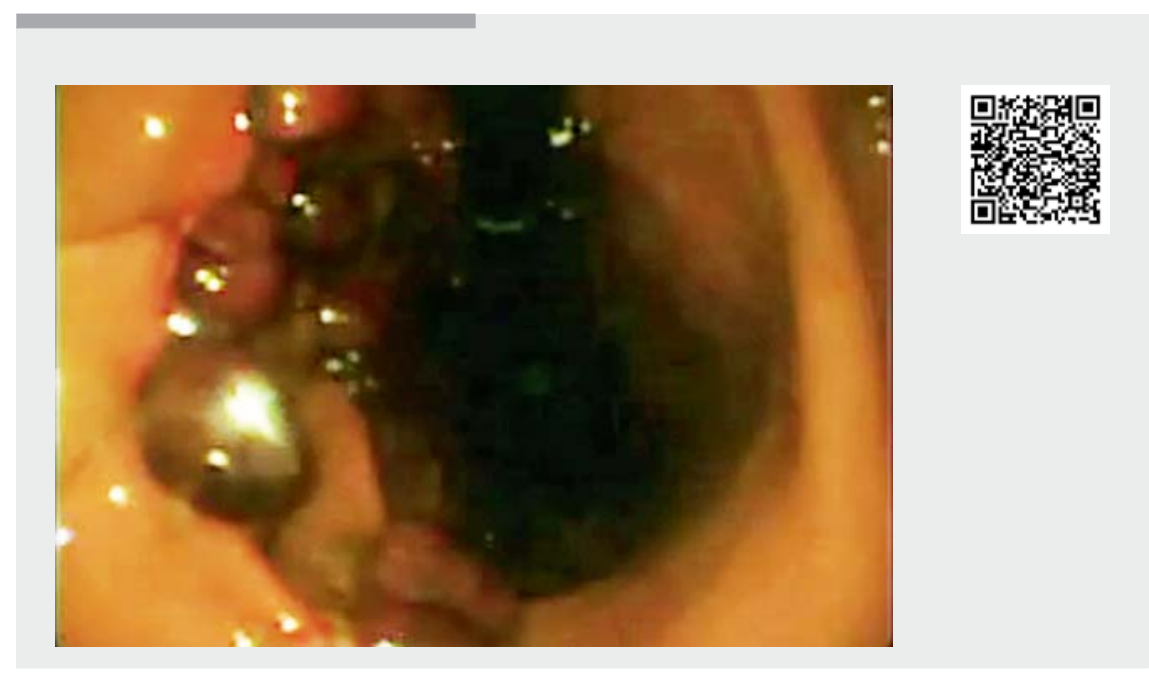

Video 1 Endoscopic band ligation for weight loss, with 33 bands applied in five parallel rows throughout the gastric body, producing well-healed linear scars on follow-up 1 month later.

( $\bullet$ Fig. 2), causing marginal narrowing of the lumen. In addition, the patient's weight had decreased from 85 to $79 \mathrm{~kg}$ and her BMI from 35.4 to $32.9 \mathrm{~kg} / \mathrm{m}^{2}$, corresponding to a $7 \%$ total weight loss and a $24 \%$ excess weight loss after 1 month. Endoscopic band ligation for weight loss is a novel technique that could assist in obesity management. The technique appears safe, repeatable, and cost-effective, with a short learning curve. Never- theless, further large-scale studies are warranted using more bands, longer caps, and prolonged follow-up to assess the efficacy and safety of the technique as a primary and secondary endoscopic weight loss procedure $[1,2]$.

Endoscopy_UCTN_Code_TTT_1AO_2AN 


\section{Competing interests}

The authors declare that they have no conflict of interest.

\section{The authors}

\section{Mohamed Abeid ${ }^{1,2}$, Tarek Kaddah ${ }^{2,3}$}

1 Endoscopy Unit, Kasr Al Aini School of Medicine, Cairo University, Cairo, Egypt

2 El Katib Hospital, Giza, Egypt

3 Anesthesia Department, Kasr Al Aini School of Medicine, Cairo University, Cairo, Egypt

\section{Corresponding author}

\section{Mohamed Abeid, MD}

GIT Endoscopy Unit, Kasr Al Aini School of Medicine, Cairo University, El Manial,

Cairo 12111, Egypt

mohamedabeid@gmail.com

\section{References}

[1] Keohane J, Berro W, Harewood GC et al. Band ligation of gastric antral vascular ectasia is a safe and effective endoscopic treatment. Dig Endosc 2013; 25: 392-396

[2] Jirapinyo P, Thompson CC. Endoscopic gastric body plication for the treatment of obesity: technical success and safety of a novel technique. Gastrointest Endosc 2020; 6: 1388-1394

Bibliography

Endoscopy 2021; 53: E287-E288

DOI 10.1055/a-1264-6360

ISSN 0013-726X

published online 8.10 .2020

(c) 2020. Thieme. All rights reserved.

Georg Thieme Verlag KG, Rüdigerstraße 14,

70469 Stuttgart, Germany
ENDOSCOPY E-VIDEOS

https://eref.thieme.de/e-videos

口. Endoscopy E-Videos is a free access online section, reporting 口if: on interesting cases and new techniques in gastroenterological endoscopy. All papers include a high quality video and all contributions are freely accessible online.

This section has its own submission website at https://mc.manuscriptcentral.com/e-videos 